\title{
Effect of Ketamine on Inflammatory and Immune Responses After Short- Duration Surgery in Obese Patients
}

\author{
Efim Roussabrov ${ }^{1}$, Joanna M. Davies ${ }^{2}$, Hana Bessler ${ }^{3}$, Lev Greemberg ${ }^{1}$, Leonid Roytblat ${ }^{1}$, \\ Israel-Zeev Yardeni ${ }^{4}$, Alan A. Artru ${ }^{*}, 2$ and Yoram Shapira ${ }^{1}$ \\ ${ }^{I}$ Division of Anesthesiology, Soroka Medical Center, Faculty of Health Science, Ben-Gurion University of the Negev, \\ Beer-Sheva, Israel \\ ${ }^{2}$ Department of Anesthesiology, University of Washington, Seattle, WA, USA \\ ${ }^{3}$ Research Institute, and ${ }^{4}$ Department of Anesthesiology, Rabin Medical Center, Golda Campus (Hasharon), Petah \\ Tiqva and The Sackler School of Medicine, Tel-Aviv University Ramat Aviv, Israel
}

\begin{abstract}
In non-obese patients ketamine decreases inflammatory responses and prevents overexpression of immune responses. Its effect in obese patients is unknown. This prospective, blinded, randomized controlled trial was designed to determine the effect of ketamine on cytokines and immune cell responses after short-duration surgery in obese patients. Thirty-six patients received either ketamine $0.15 \mathrm{mg} / \mathrm{kg}$ IV prior to induction of general anesthesia, or an equal volume of normal saline. Cytokine concentrations and immune cell responses were determined pre-operatively and at 4,24 , and $48 \mathrm{~h}$ after operation. Interleukin (IL)-6 production was significantly greater in the control group $(126.0 \pm 18.8 \mathrm{ng} / \mathrm{ml}$, mean \pm SEM, $\mathrm{n}=19)$ than in the ketamine group $(57.9 \pm 8.4 \mathrm{ng} / \mathrm{ml})$ at $4 \mathrm{~h}$. At other time periods IL- 6 and tumor necrosis factor $\alpha$ increased and IL-2, lymphocyte proliferation, and natural killer cell cytotoxity decreased compared to pre-operative values in the control group but not in the ketamine group. We conclude that effects of ketamine on inflammatory and immune responses after short-duration surgery in obese patients are similar to those previously reported in non-obese patients.
\end{abstract}

Keywords: Ketamine, cytokines, interleukins, inflammation, immune response.

\section{INTRODUCTION}

The human immune system is complex, consisting of both inflammatory and immune cell responses. Major surgery causes release of pro-inflammatory cytokines which, in excessive amounts, may cause undesirable consequences such as postoperative complications, immune cell suppression, and end-organ injury, resulting in multiple organ failure and death [1-3]. In contrast, release of anti-inflammatory cytokines together with immune cell proliferation and natural killer (NK) cell activity attenuate and regulate proinflammatory mediators [1-3].

Ketamine, an N-methyl-D-aspartate (NMDA) receptor antagonist, may favourably affect the balance between inflammatory and immune cell responses in humans. There are over 30 published studies in humans and the majority report that ketamine decreases inflammatory responses and prevents overexpression of immune responses [4-35] (Table 1). However, none of these reports studied the effect of ketamine in obese patients.

Obesity is becoming increasingly prevalent and is associated with metabolic, hormonal, and physiologic changes, the pathophysiologic consequence of which affect every major organ system [36]. There is an extensive literature examining the relationship between obesity and inflammation. Chronic

*Address correspondence to this author at the Department of Anesthesiology, Box 356540, UWMC, 1959 NE Pacific St., Seattle, WA 98195, USA; Tel: 2065984260; Fax: 2065984544; E-mail: artruaa@u.washington.edu inflammation is an integral component of obesity, and obesity is the strongest independent predictor of inflammation [37-39]. It is not certain whether the metabolic, hormonal, and physiologic changes occurring with obesity affect the inflammatory and/or immune responses to ketamine previously reported in non-obese patients. The present study was designed to determine, in obese patients, the effect of ketamine on cytokines [interleukin (IL)- $1 \beta$, IL-2, IL-6, and tumor necrosis factor (TNF)- $\alpha$ ], a specific immunity cell response (lymphocyte proliferation), and a nonspecific immunity cell response (NK cell activity).

\section{MATERIALS AND METHODS}

The study was approved by the institution's Human Subjects Helsinki committee of the Rabin Medical Center. Informed, written consent was obtained from all the patients. Thirty-six obese (as defined by Roizen and Fleisher, body mass index greater than $28 \mathrm{~kg} / \mathrm{m}^{2}$ ), non-smoking, male and female patients between the ages of 23-67, with an ASA status of 1-II undergoing elective gastric or uterine surgery participated in the study [36]. Exclusion criteria for patient selection were endocrine disorders, immune system disorders, patients on immunosuppressive treatment, chronic inflammatory disease, patients with any sign of infection after surgery, malignant disease, allergy to ketamine, kidney or liver disorders, and blood transfusion perioperatively. The decision to enroll 36 patients was based on two-sided sample size determination (power analysis) assuming $\sigma$ (standard deviation) of 0.4 for our primary measures (i.e., cytokine 
Table 1. Previously Reported Effects of Ketamine in Humans or Human Cells

\begin{tabular}{|c|c|c|}
\hline Reference & Finding & Source \\
\hline \multicolumn{3}{|c|}{ Decreased Pro-Inflammatory Factors or Exerted Anti-Inflammatory Effect } \\
\hline Roytblat et al. [13] & IL-6 & adult surgical patients (hysterectomy) \\
\hline Larsen et al. [17] & IL1 $\beta$ and TNF & cultured whole blood \\
\hline Roytblat et al. [18] & IL-6 & adult surgical patients (cardiac) \\
\hline Zahler et al. [20] & reactivity & leukocytes \\
\hline Kawasaki et al. [22] & IL-6 and 8 , TNF alpha & whole blood \\
\hline Weigand et al. [23] & IL-6, CD 18, CD 62 & neutrophils \\
\hline Cao et al. [25] & IL-6 and 8 & adult surgical patients (cardiac) \\
\hline Hoff et al. [26] & TNF alpha & cultured whole blood \\
\hline Kawasaki et al. [27] & IL- 6 and 8, TNF & whole blood \\
\hline Xia et al. [35] & IL-1 and 6, TNF alpha & burn patients \\
\hline \multicolumn{3}{|c|}{ No Change in Inflammatory Factors } \\
\hline Marone et al. [7] & Histamine & basophils, mast cells (skin, lung, heart) \\
\hline Larsen et al. [17] & IL-10 & cultured whole blood \\
\hline Zahler et al. [20] & IL-6 and 8 , adhesion molecules & leukocytes, cultured endothelial cells \\
\hline Takano et al. [30] & IL- 6 and 10 & mononuclear cells \\
\hline Zeyneloglu et al. [32] & IL-6 & infant surgical patients (cardiac) \\
\hline \multicolumn{3}{|c|}{ Increased Pro-Inflammatory Factors } \\
\hline Stellato et al. [4] & Histamine & basophils, mast cells (skin, lung, heart) \\
\hline Rossano et al. [6] & IL-4 and 6, TNF & monocytes, lymphocytes \\
\hline \multicolumn{3}{|c|}{ No Change in Immune Responses } \\
\hline Hashimoto et al. [5] & natural killer cell activity & adult surgical patients \\
\hline Davidson et al. [9] & phagocytosis, respiratory burst activity & polymorphonuclear leukocytes \\
\hline Krumholz et al. [10] & bactericidal activity & polymorphonuclear leukocytes \\
\hline Toyota et al. [11] & phagocytosis & polymorphonuclear leukocytes \\
\hline Nishina et al. [14] & chemotaxis, reactive oxygen species & neutrophils \\
\hline Hellar et al. [15] & phagocytosis, burst activity & neutrophils, monocytes \\
\hline Larsen et al. [17] & CD 14, HLA-DR & cultured whole blood \\
\hline Krumholz et al. [21] & chemotaxis & polymorphonuclear eosinophilic leukocytes \\
\hline Loop et al. [31] & NFkB & T lymphocytes \\
\hline Bentley et al. [33] & natural killer cell activity & adult surgical patients (oral maxillofacial surgery) \\
\hline Buyukkocak et al. [34] & acute phase proteins & pediatric surgical patients (circumcision) \\
\hline \multicolumn{3}{|c|}{ Decrease Immune Responses } \\
\hline Weiss et al. [8] & oxygen radical production & polymorphonuclear leukocytes \\
\hline Krumholz et al. [12] & phagocytosis, bactericidal activity & polymorphonuclear cells \\
\hline Nishina et al. [14] & phagocytosis & neutrophils \\
\hline Heller et al. [15] & phagocytosis, bacterial elimination & monocytes \\
\hline Hofbauer et al. [16] & migration & leukocytes \\
\hline Krumholz et al. [19] & chemotaxis & monocytes \\
\hline Weigand et al. [23] & oxygen radical production & neutrophils \\
\hline Sakai et al. [24] & NFkB & cultured glioma cells \\
\hline Lewis et al. [28] & proliferation & mononuclear cells \\
\hline \multicolumn{3}{|c|}{ Increased Immune Responses } \\
\hline Krumholz et al. [29] & non-oxidative bactericidal activity & polymorphonuclear leukocytes \\
\hline
\end{tabular}

$\mathrm{IL}=$ interleukin; $\mathrm{NFkB}=$ nuclear transcription factor kappa B; CD18 = $\beta$-integrin; CD 62 = L-selectin; CD14 = lipopolysaccharide recognition; HLA-DR = major histocompatability complex class II, human leukocyte locus A; TNF = tumor necrosis factor. 
concentrations, lymphocyte proliferation, and NK cell activity; based on preliminary data), a $30 \%$ difference between $\mu_{0}$ and $\mu_{1}$ (difference between means), power of 0.85 , significance of 0.05 , an unbalanced randomization design, and a minimum number of patients failing to complete the study after ascertaining that no exclusion criteria applied.

Ninety minutes before surgery, all patients were premedicated with diazepam, 5-10 mg orally, and upon arrival in the operating room received midazolam, 2-3 $\mathrm{mg}$ IV. The patients were then randomly divided in two groups: the treatment group (17 patients) received ketamine, $0.15 \mathrm{mg} \mathrm{kg}^{-}$ ${ }^{1} \mathrm{IV}$, five minutes before induction of general anaesthesia and the control group (19 patients) received a similar volume of normal saline 5 minutes before induction of anaesthesia. Selection of the dose of ketamine was based on a previous report that this dose suppressed IL-6 productions in nonobese patients having abdominal hysterectomy [13]. Anaesthesia was induced with fentanyl $2-3 \mathrm{mcg} \mathrm{kg}^{-1}$ and thiopental $4-6 \mathrm{mg} \mathrm{kg}{ }^{-1} \mathrm{IV}$. Vecuronium, $0.1 \mathrm{mg} \mathrm{kg}^{-1} \mathrm{IV}$ was given for muscle relaxation. Anaesthesia was maintained with nitrous oxide $60-70 \%$ and isoflurane $1.0-1.5 \%$ (inspired concentrations) in oxygen. Additional fentanyl (1-2 $\left.\mathrm{mcg} \mathrm{kg}^{-1}\right)$ was given as needed to maintain a mean arterial blood pressure within $20 \%$ of baseline values. The patients received upper body forced-air warming, and intravenous fluids were warmed to $37^{\circ}$.

Venous blood samples $(15 \mathrm{ml})$ were collected just before administration of ketamine or normal saline and at 4, 24, 48, and $72 \mathrm{~h}$ after operation for determination of cytokines and immune cell responses. The persons performing sample analysis were blinded as to whether the sample originated from treatment or control patients. Peripheral blood mononuclear (PBMN) cells were isolated from heparinized venous blood using a histopaque (Sigma) gradient centrifugation, washed twice in RPMI-1640 medium containing 1\% penicillin, streptomycin and nystatin and supplemented with $10^{\text {th }}$ fetal calf serum (FCS), designated as complete medium (CM), and then suspended in FCS containing $10 \%$ dimethyl sulphoxide (DMSO, Sigma) and frozen at $-70^{\circ} \mathrm{C}$ until used. On the day of assay, the cells were thawed quickly, washed three times in $\mathrm{CM}$ and their viability tested by trypan blue dye exclusion. The viability was over $95 \%$.

For IL-1 $\beta$, IL- 6 and TNF- $\alpha$ assay, PBMN cells $\left(\times \times 10^{6}\right)$ suspended in $1 \mathrm{ml}$ of RPMI-1640 supplemented with $5 \%$ FCS were incubated for $24 \mathrm{~h}$ in the presence of $10 \mathrm{ng} \mathrm{ml}^{-1}$ lipopolysaccharide (E. coli, Sigma). For IL-2 production, $2 \times 10^{6}$ PBMN cells were suspended in $1 \mathrm{ml}$ of CM and incubated for $48 \mathrm{~h}$ with $1 \%$ phytohemagglutinin (PHA-M, Difco). These concentrations of lipopolysaccharide and PHA previously were reported to induce maximal release of the respective cytokines [40, 41]. Following incubation, the culture media were collected, the cells were removed by centrifugation, and the supernatants were kept at $-70^{\circ} \mathrm{C}$ until assayed for cytokine content. Cytokine concentration in the supernatants was tested using ELISA kits specific for human IL-1 $\beta$ (Biosource International, Camarillo, CA), IL-6 and TNF- $\alpha$, (Pharmingen, San Diego, CA), and IL-2 (R\&D Systems, Minneapolis, MN, USA). The detection level of these cytokines in the assays was $30 \mathrm{pg} \mathrm{ml}^{-1}$ for IL-1 $\beta$, IL-2 and TNF- $\alpha$ and $15 \mathrm{pg} \mathrm{ml}^{-1}$ for IL-6.
$0.1 \mathrm{ml}$ of PBMN cell suspension $\left(2 \times 10^{6}\right.$ cells $\left.\mathrm{ml}^{-1}\right)$ was aliquoted into each well of 96-well plates (flat bottom, Nunc) containing $0.1 \mathrm{ml}$ of CM or PHA, concanavalin A (Con A, 10 $\mu \mathrm{g} \mathrm{ml}^{-1}$ ), or pokeweed mitogen (PWM, Sigma, $20 \mu \mathrm{g} \mathrm{ml}^{-1}$ ). Cultures were set up in triplicate, with each culture in a single well, and were incubated for 3 days. $0.5 \mu \mathrm{CI} /$ well of ${ }^{3} \mathrm{H}-$ TdR (methyl- ${ }^{3} \mathrm{H}$-thymidine, $5 \mu \mathrm{CI} \mathrm{mmol}^{-1}$, Amersham, England) was added $18 \mathrm{~h}$ before harvesting. Radioactivity was measured using a liquid scintillation counter (LKB model $3380)$.

Cytotoxicity was assessed using a standard chromium specific release assay with a ${ }^{51} \mathrm{Cr}$ labeled $\mathrm{K} 562$ cell line used as target cells and PBMN cells serving as effector cells. Final effector to target (E:T) ratio was 100:1. Following $4 \mathrm{hrs}$ of incubation at $37^{\circ} \mathrm{C}$, the supernatants were collected, and the radioactivity was measured using a gamma counter (LKB). All reactions were carried out in triplicate and the specific ${ }^{51} \mathrm{Cr}$ release was calculated as described previously [42].

\section{Statistics}

Categorical data were described with frequency counts and were compared between groups using Fischer's exact test. Parametric data were normally distributed, were expressed as mean \pm SEM, and were compared within and between groups using repeated measures analysis of variance (ANOVA) followed by post hoc testing with StudentNewman-Keuls multiple comparison test. $\mathrm{P}$ values $<0.05$ were considered significant.

\section{RESULTS}

The treatment and control groups were similar with respect to age, gender, body weight, ASA status, and type and duration of surgery (Table 2). None of the patients required a blood transfusion and none dropped out of the study. The fentanyl dose for induction of anaesthesia, $245 \pm 48 \mathrm{mcg}$ and $236 \pm 45 \mathrm{mcg}$, and the fentanyl dose for maintenance of anaesthesia, $142 \pm 28 \mathrm{mcg}$ and $140 \pm 27 \mathrm{mcg}$, did not differ significantly between the control and ketamine groups. The effect of pre-induction ketamine, compared with saline, on the production of cytokines and immune cell responses is summarized in Table 3.

Table 2. Patient Demographics

\begin{tabular}{|c|c|c|}
\hline & Control Group & Ketamine Group \\
\hline Number of Patients & 19 & 17 \\
\hline $\operatorname{Sex}(M / F)$ & $5 / 14$ & $4 / 13$ \\
\hline Age (years) & $43.5 \pm 10.3$ & $39.0 \pm 10.7$ \\
\hline Body Mass Index (kg/m²) & $34.7 \pm 7.4$ & $34.3 \pm 8.3$ \\
\hline Body Weight (kg) & $97.5 \pm 26.3$ & $95.4 \pm 29.9$ \\
\hline ASA Physical Status & $\mathrm{I}=8, \mathrm{II}=11$ & $\mathrm{I}=7, \mathrm{II}=10$ \\
\hline Type of Surgery (gastric/uterine) & $9 / 10$ & $9 / 8$ \\
\hline Duration of Surgery (min) & $69 \pm 25$ & $75 \pm 22$ \\
\hline
\end{tabular}

Values expressed as means $+/$ - SEM. 
Table 3. Cytokine and Immune Responses

\begin{tabular}{|c|c|c|c|c|c|c|}
\hline Response & Group & Preop & $4 \mathrm{hrs}$ & 24 hrs & $48 \mathrm{hrs}$ & $72 \mathrm{hrs}$ \\
\hline IL-1 $\beta$ & Control & $6.5 \pm 0.3$ & $8.2 \pm 0.9$ & $8.8 \pm 0.7$ & $8.4 \pm 0.9$ & $8.4 \pm 0.9$ \\
\hline$\left(\mathrm{ng} \mathrm{ml}^{-1}\right)$ & Ketamine & $6.4 \pm 0.5$ & $8.1 \pm 0.8$ & $8.9 \pm 0.7$ & $9.2 \pm 0.8^{*}$ & $8.8 \pm 0.9$ \\
\hline IL-6 & Control & $57.4 \pm 5.0$ & $126.0 \pm 18.8$ & $136.4 \pm 14.1^{*}$ & $141.2 \pm 17.1^{*}$ & $140.6 \pm 31.6^{*}$ \\
\hline$\left(\mathrm{ng} \mathrm{ml}{ }^{-1}\right)$ & Ketamine & $52.7 \pm 7.5$ & $57.9 \pm 8.4 \#$ & $110.4 \pm 20.0$ & $105.5 \pm 9.5$ & $102.7 \pm 14.3$ \\
\hline TNF- $\alpha$ & Control & $12.5 \pm 0.8$ & $15.4 \pm 1.3$ & $15.0 \pm 1.7$ & $16.0 \pm 1.7$ & $16.6 \pm 1.2^{*}$ \\
\hline$\left(\mathrm{ng} \mathrm{ml}{ }^{-1}\right)$ & Ketamine & $11.4 \pm 1.1$ & $11.8 \pm 1.1$ & $14.9 \pm 1.2$ & $16.5 \pm 1.6$ & $15.9 \pm 2.2$ \\
\hline IL-2 & Control & $5.0 \pm 0.5$ & $3.6 \pm 0.6$ & $3.2 \pm 0.5 \dagger$ & $3.2 \pm 0.5 \dagger$ & $4.0 \pm 0.5$ \\
\hline$\left(\mathrm{ng} \mathrm{m}^{-1}\right)$ & Ketamine & $5.5 \pm 0.5$ & $4.6 \pm 0.6$ & $4.5 \pm 0.5$ & $4.3 \pm 0.5$ & $4.8 \pm 0.4$ \\
\hline Lymphocyte & Control & $19.2 \pm 1.7$ & $16.4 \pm 2.1$ & $14.3 \pm 1.7 \dagger$ & $18.3 \pm 2.1$ & $17.3 \pm 1.7$ \\
\hline proliferation $\left(\mathrm{Cpm} \times 10^{3)}\right.$ & Ketamine & $19.9 \pm 1.6$ & $17.4 \pm 1.6$ & $17.3 \pm 1.5$ & $18.1 \pm 2.1$ & $18.2 \pm 1.7$ \\
\hline NK Cell & Control & $35.4 \pm 2.7$ & $40.8 \pm 3.1$ & $22.4 \pm 2.4 \dagger$ & $25.6 \pm 2.5^{*}$ & $30.5 \pm 2.6$ \\
\hline Cytotoxicity (\%) & Ketamine & $33.5 \pm 3.4$ & $34.0 \pm 3.5$ & $24.9 \pm 3.4$ & $23.5 \pm 1.9 *$ & $26.2 \pm 2.3$ \\
\hline
\end{tabular}

IL-1 $\beta$ = Interleukin-1 $\beta$, IL-2 = Interleukin-2, IL-6 = Interleukin-6, TNF- $\alpha=$ Tumor necrosis factor- $\alpha$, Lymphocyte proliferation = Phytohemagglutinin-induced response (concana-

valin A- and pokeweed mitogen-induced responses not shown), NK = Natural killer.

$* \mathrm{p}<0.05$ vs preoperative value.

$\dagger \mathrm{p}<0.01$ vs preoperative value.

$\# \mathrm{p}<0.05$ between groups.

$\mathrm{N}=19$ in the Control group and $\mathrm{N}=17$ in the Ketamine group.

Values expressed as mean $\pm \mathrm{SEM}$

Before operation, concentrations of cytokines and immune responses did not differ between groups. Postoperatively, IL-6 production was significantly greater in the control group $\left(126.0 \pm 18.8 \mathrm{ng} \mathrm{ml}^{-1}\right.$, mean \pm SEM) than in the ketamine group $\left(57.9 \pm 8.4 \mathrm{ng} \mathrm{ml}^{-1}\right)$ at $4 \mathrm{~h}$. At 24,48 , and 72 h, IL-6 production increased compared to preoperative values in the control group but not in the ketamine group. At 48 $\mathrm{h}$, IL-1 $\beta$ increased in the ketamine group but not in controls. At $72 \mathrm{~h}$ TNF- $\alpha$ increased in controls but not in the ketamine group.

Production of IL-2, PHA-stimulated lymphocyte proliferation, and NK cell cytotoxicity all decreased at $24 \mathrm{~h}$ compared to preoperative values in the control group but not in the ketamine group. Con A- and PWM-induced proliferation did not change significantly during the $72 \mathrm{~h}$ after operation in either group (data not shown).

\section{DISCUSSION}

\section{Cytokine and Immune Cell Responses}

IL-6 is an integral pro-inflammatory cytokine involved in the acute phase response to injury and infection [43]. It is inducible in nearly every human tissue and cell type and production can be stimulated by numerous factors, including TNF- $\alpha$ and IL-1. It is the inflammatory mediator most consistently identified systemically after elective surgery, increasing within $1-3 \mathrm{~h}$ after laparotomy, peaking at $4-24 \mathrm{~h}$ and remaining elevated for $48-72 \mathrm{~h}$ [44]. The greater the surgical trauma, the greater the serum IL-6 response. For example, abdominal surgery produces a bigger response than hip replacement [2]. It follows that most randomized studies show laparotomy triggering a larger inflammatory response than laparoscopy [13, 44-46]. Laparoscopic surgery appears to induce a smaller injury, resulting in proportionally decreased immunological changes, although the exact mechanism is unclear [47]. Comparatively, IL-1 $\beta$ and TNF- $\alpha$ are detectable in much lower serum concentrations than IL-6 after elective surgery. However, hemorrhagic and septic shock both result in significantly elevated levels of IL-1 $\beta$, TNF- $\alpha$ and IL-6, which are associated with an increased risk of acute respiratory distress syndrome, multiple organ failure, and death [48-50]. In trauma patients, increased IL-6 levels are associated with the development of infection [4850]. The enhanced local release of inflammatory cytokines associated with abdominal surgery is thought to be related to postoperative ileus secondary to inhibition of muscularis function $[44,51]$.

Serum concentrations of IL-2, a promoter of T lymphocyte proliferation, and host defense against infection, are reduced as early as $2 \mathrm{~h}$ after surgical trauma and may remain depressed for up to five days after trauma-hemorrhage [52]. $\mathrm{T}$ lymphocytes are one component of specific immunity in humans providing antimicrobial and antitumor defense. Hallmarks of $\mathrm{T}$ lymphocytes are specificity and memory. CD4 T lymphocytes promote cell mediated immunity or humoral immunity and allergy, while CD8 T lymphocytes destroy major histocompatibility complex-bearing cells. NK cells are one component of nonspecific immunity in humans. NK cells possess large granules containing enzymes that induce apoptosis in target cells and can mediate death of Fasbearing targets through the action of Fas ligand. NK cells lack the specificity of $\mathrm{T}$ lymphocytes, instead relying on the ability to detect abnormally low expression of class 1 major histocompatibility complex molecules, as occurs in viralinfected cells. Proliferation of PHA-stimulated lymphocytes and NK cell cytotoxicity have been found to be suppressed postoperatively [44, 52].

\section{Results of the Present Study}

Our results demonstrate that the effect of ketamine on inflammatory and immune responses in obese patients is 
similar to that previously reported in non-obese patients [4$35]$. In previous studies in humans ketamine decreased proinflammatory factors or exerted an anti-inflammatory effect in 10 studies, caused no change in 5 studies, and increased pro-inflammatory factors in 2 studies. As regards immune responses, ketamine caused no change in 11 studies, suppressed immune responses in 9 studies, and augmented in immune responses in one study [4-35]. Alterations in inflammatory and immune responses may affect clinical outcomes such as postoperative pneumonia, membrane permeability, acute lung injury, ARDS, wound infections, and sepsis. In general, attenuation of cytokine responses is beneficial. However, in certain clinical situations such as in the immunocompromised patient, blunting the release of inflammatory mediators and failure of neutrophil migration into an inflamed lung, may predispose to a greater risk of pulmonary infections. In addition, cytokine responses are sensitive and are affected by many factors. Altering ventilation strategy alone may modify lung cytokine responses to lipopolysaccharide. Positive pressure ventilation in the absence of anesthesia may also exacerbate inflammatory responses.

Ketamine may have direct effects on pro-inflammatory, anti-inflammatory and immune responses, or may influence those responses indirectly by reducing postoperative pain. Pain itself is a promoter of pro-inflammatory cytokine production and suppression of IL-2, and therefore ketamine may have additional benefits in the postoperative patient secondary to its preemptive analgesic effects and opioid sparing properties. Several studies have shown that adding subanaesthetic doses of ketamine to general anaesthesia reduces postoperative pain and opioid requirements in a variety of surgeries, including major abdominal, arthroscopic knee, laparoscopic gynecologic, and adenocarcinoma surgery [5356]. Ketamine acts as a noncompetitive antagonist at NMDA receptors, which play an important role in the concept of the "wind-up" phenomenon and pain sensitization. It is also thought to mediate pain by interaction with spinal $\mu$ receptors and via activation of the descending pain inhibitory monoaminergic pathways [53]. It is possible that the same results seen here with ketamine may have been found with any analgesic agent.

Volitile anesthetics and thiopental may have affected the inflammatory and immune responses we examined. Under controlled conditions, volatile anesthetics tend to increase cytokine formation and appear to enhance inflammatory responses. In contrast, using models of acute lung injury by stimulation with lipopolysaccaride, E Coli endotoxin, or interleukin 1, volatile anesthetics appear to exert antiinflammatory effects including, inhibition of cytokine formation; reduction of neutrophil migration into the lung interstitium and alveolar space; and attenuation of protein leakage and publmonary edema [57-60].

In summary, ketamine given at the time of induction of anaesthesia attenuated production of IL-6, did not significantly change concentrations of other cytokines in comparison to concentrations in controls, and tended to preserve immune responses after short-duration surgery in obese patients. These effects are similar to those generally reported in previous studies of non-obese patients.

\section{REFERENCES}

[1] Guirao X, Lowry SF. Biologic control of injury and inflammation: much more than too little too late. World J Surg 1996; 20: 437-46.

[2] Cruickshank AM, Fraser SD, Burns HJ, Van Damme J, Shenkin A. Response of serum interleukin-6 in patients undergoing elective surgery of varying severity. Clin Sci 1990; 79: 161-5.

[3] Koenig A, Koenig UD, Heicappal R, Stoeckel H. Differences in lymphocyte mitogenic stimulation pattern depending on anaesthesia and operative trauma: I. Halothane-nitrous oxide anaesthesia. Eur J Anaesthesiol 1987; 4: 17-24.

[4] Stellato C, Casolaro V, Ciccarelli A, Mastronardi P, Mazzarella B, Marone G. General anaesthetics induce only histamine release selectively from human mast cells. Br J Anaesth 1991; 67: 751-8.

[5] Hashimoto H, Araki I, Sato T, Matsuki A. Clinical Study on total intravenous anesthesia with droperidol, fentanyl and ketamine-7. Effects on natural killer cell activity. Masui 1991; 40: 912-7.

[6] Rossano F, Tufano R, Cipollaro de L'Ero G, Servillo G, Baroni A, Tufano MA. Anesthetic agents induce human mononuclear leucocytes to release cytokines. Immunopharmacol Immunotoxicol 1992; 14: 439-50.

[7] Marone G, Stellato C, Mastronardi P, Mazzarella B. Mechanisms of activation of human mast cells and basophils by general anesthetic drugs. Ann Fr Anesth Reanim 1993; 12: 116-25.

[8] Weiss M, Birkhahn A, Mettler S, Schneider M, Wernet P. Stereoselective suppression of neutrophil function by ketamine? Immunopharmacol Immunotoxicol 1995; 17: 91-107.

[9] Davidson JA, Soom SJ, Pearsall FJ, Zhang P, Ramsay G. Comparison of the effects of four i.v. anaesthetic agents on polymorphonuclear leucocyte function. Br J Anaesth 1995; 74: 315-8.

[10] Krumholz W, Demel C, Jung S, Meuthen G, Knecht J, Hempelmann G. The effects of thiopentone, etomidate, ketamine and midazolam on several bactericidal functions of polymorphonuclear leucocytes in vitro. Eur J Anaesthesiol 1995; 12: 141-6.

[11] Toyota S, Moriyama M, Otake T, et al. Effect of anaesthetic agents on the phagocytic function of human polymorphonuclear leukocytes through analysis with a phagocytic plaque method. Inflamm Res 1995; 44: 204-6.

[12] Krumholz W, Endrass J, Hempelmann G. Inhibition of phagocytosis and killing of bacteria by anaesthetic agents in vitro. Br J Anaesth 1995; 75: 66-70.

[13] Roytblat L, Roy-Shapira A, Greemberg L. Preoperative low does ketamine reduces serum Interleukin-6 response after abdominal hysterectomy. Pain Clin 1996; 9: 327-34.

[14] Nishina K, Akamatsu H, Mikawa K, et al. The inhibitory effects of thiopental, midazolam, and ketamine on human neutrophil functions. Anesth Analg 1998; 86: 159-65.

[15] Heller A, Heller S, Blecken S, Urbaschek R, Koch T. Effects of intravenous anesthetics on bacterial elimination in human blood in vitro. Acta Anaesthesiol Scand 1998; 42: 518-26.

[16] Hofbauer R, Moser D, Hammerschmidt V, Kapiotis S, Frass M. Ketamine significantly reduces the migration of leukocytes through endothelial cell monolayers. Crit Care Med 1998; 26: 1545-9.

[17] Larsen B, Hoff G, Wilhelm W, Buchinger H, Wanner GA, Bauer M. Effect of intravenous anesthetics on spontaneous and endotoxin-stimulated cytokine response in cultured human whole blood. Anesthesiology 1998; 89: 1218-27.

[18] Roytblat L, Talmor D, Rachinksky M, et al. Ketamine attenuates the interleukin-6 response after cardiopulmonary bypass. Anesth Analg 1998; 87: 266-71.

[19] Krumholz W, Reussner D, Hempelmann G. The influence of several intravenous anaesthetics on the chemotaxis of human monocytes in vitro. Eur J Anaesthesiol 1999; 16: 547-9.

[20] Zahler S, Heindl B, Becker BF. Ketamine does not inhibit inflammatory responses of cultured human endothelial cells but reduces chemotactic activation of neutrophils. Acta Anaesthesiol Scand 1999; 43: 1011-6.

[21] Krumholz W, Abdulle O, Knecht J, Hempelmann G. Effects of i.v. anaesthetic agents on the chemotaxis of eosinophils in vitro. $\mathrm{Br} \mathrm{J}$ Anaesth 1999; 83: 333-5.

[22] Kawasaki T, Ogata M, Kawasaki C, Ogata J, Inoue Y, Shigematsu A. Ketamine suppresses proinflammatory cytokine production in human whole blood in vitro. Anesth Analg 1999; 89: 665-9.

[23] Weigand MA, Schmidt H, Zhao Q, Plaschke K, Martin E, Bardenheuer HJ. Ketamine modulates the stimulated adhesion molecule expression on human neutrophils in vitro. Anesth Analg 2000; 90: 206-12. 
[24] Sakai T, Ichiyama T, Whitten CW, Giesecke AH, Lipton JM. Ketamine suppresses endotoxin-induced NF-kappaB expression. Can J Anaesth 2000; 47: 1019-24.

[25] Cao DQ, Chen YP, Zou DQ. Effects of katamine on cardiopulmonary bypass-induced interleukin- 6 and interleukin- 8 response and its significance. Hunan Yi Ke Da Xue Xue Bao 2001; 26: 350-2.

[26] Hoff G, Bauer I, Larsen B, Bauer M. Modulation of endotoxinstimulated TNF-alpha gene expression by ketamine and propofol in culture human whole blood. Anaesthesist 2001; 50: 494-9.

[27] Kawasaki C, Kawasaki T, Ogata M, Nandate K, Shiegematsu A. Ketamine isomers suppress superantigen-induced proinflammatory cytokine production in whole blood. Can J Anaesth 2002; 48: 81923.

[28] Lewis E, Rogachev B, Shaked G, Douvdevani A. The in vitro effects of ketamine at large concentrations can be attributed to a nonspecific cytostatic effect. Anesth Analg 2001; 92: 927-9.

[29] Krumholz W, Weidenbusch H, Menges T, Keller G, Hempelmann $\mathrm{G}$. The influence of intravenous anaesthetics on the activity of enzymes released from polymorphonuclear leucocytes in vitro. Eur J Anaesthesiol 2001; 18: 151-8.

[30] Takaono M, Yogosawa T, Okawa-Takatsuji M, Aotsuka S. Effects of intravenous anesthetics on interleukin (IL)- 6 and IL-10 production by lipopolysaccharide-stimulated mononuclear cells from healthy volunteers. Acta Anaesthesiol Scand 2002; 46: 176-9.

[31] Loop T, Liu Z, Humar M, et al. Thiopental inhibits the activation of nuclear factor kappaB. Anesthesiology 2002; 96: 1202-13.

[32] Zeyneloglu P, Donmez A, Bilezikci B, Mercan S. Effects of ketamine on serum and tracheobronchial apirate interleukin-6 levels in infants undergoing cardiac surgery. J Cardiothorac Vasc Anesth 2005; 19: 329-33.

[33] Bentley MW, Stas JM, Johnson JM, Viet BC, Garrett N. Effects of preincisional ketamine treatment on natural killer cell activity and postoperative pain management after oral maxillofacial surgery. AANA J 2005; 73: 427-36.

[34] Buykkocak U, Caglayan F, Caglayan O, et al. Anaesthesia and the acute phase protein response in children undergoing circumcision. Mediators Inflamm 2005; 5: 312-5

[35] Xia JG, Peng J, Xiao H, Zhang J, Sun JB. Effect of intravenous patient-controlled intravenous analgesia with small dose of ketamine during shock stage on cytokine balance in patients with severe burn. Zhongguo Wei Zhong Bing Ji Jiu Yi Xue 2006; 18: 325 .

[36] Roizen MF, Fleisher LA. Anesthetic Implications of Concurrent Diseases. In Miller RD (ed): Miller's Anesthesia, $6^{\text {th }}$ edition. Philadelphia: Elsevier Churchill Livingstone, 2005: 1017-1149.

[37] Nathan C. Epidemic Inflammation: Pondering Obesity. Mol Med 2008 Apr 20 [Epub ahead of print]

[38] Hamer M, Stamatakis E. The accumulative effects of modifiable risk factors on inflammation and haemostasis. Brain Behav Immun 2008 Apr 12 [Epub ahead of print]

[39] Weisberg SP, Leibel R, Tortoriello DV. Dietary curcumin significantly improves obesity-associated inflammation and diabetes in mouse models of diabesity. Endocrinology 2008 Apr 10 [Epub ahead of print]

[40] Inamizu T, Chang MP, Makinodan T. Influence of age on the production and regulation of interleukin-1 in mice. Immunology 1985; 55: 447-55.

[41] Beilin B, Shavit Y, Trabekin E, et al. The effects of postoperative pain management on immune response to surgery. Anesth Analg 2003; 97: 822-7.
[42] Beilin B, Shavit Y, Hart J, et al. Effects of anesthesia based on large versus small doses of fentanyl on natural killer cell cytotoxity in the perioperative period. Anesth Analg 1996; 82: 492-7.

[43] Biffl WL, Moore EE, Moore FA, Peterson VM. Interleukin-6 in the injured patient. Marker of injury or mediator of inflammation? Ann Surg 1996; 224: 647-64.

[44] Sido B, Teklote JR, Hartel M, Friess H, Buchler MW. Inflammatory response after abdominal surgery. Best Pract Res Clin Anaesthesiol 2004; 18: 439-54.

[45] Leung KL, Lai PB, Ho RL, et al. Systemic cytokine response after laparoscopic-assisted resection of rectosigmoid carcinoma: A prospective randomized trial. Ann Surg 2000; 231: 506-11.

[46] Wu FP, Sietses C, von Blomberg BM, van Leeuwen PA, Meijer S, Cuesta MA. Systemic and peritoneal inflammatory response after laparoscopic or conventional colon resection in cancer patients: a prospective, randomized trial. Dis Colon Rectum 2004; 46: 147-55.

[47] Novitsky YW, Litwin DE, Callery MP. The net immunologic advantage of laparoscopic surgery. Surg Endosc 2004; 18: 1411-9.

[48] Roumen RM, Hendriks T, van der Ven-Jongekrijg J, et al. Cytokine patterns in patients after major vascular surgery, hemorrhagic shock, and severe blunt trauma. Relation with subsequent adult respiratory distress syndrome and multiple organ failure. Ann Surg 1993; 218: 769-76.

[49] Martin C, Boisson C, Haccoun M, Thomachot L, Mege JL. Patterns of cytokine evolution (tumor necrosis factor-alpha and interleukin6) after septic shock, hemorrhagic shock, and severe trauma. Crit Care Med 1997; 25: 1813-9.

[50] Casey LC, Balk RA, Bone RC. Plasma cytokine and endotoxin levels correlate with survival in patients with the sepsis syndrome. Ann Intern Med 1993; 119: 771-8.

[51] Kalff JC, Turler A, Schwarz NT, et al. Intra-abdominal activation of a local inflammatory response within the human muscularis externa during laparotomy. Ann Surg 2003; 237: 301-15.

[52] Angele MK, Faist E. Clinical review: immunodepression in the surgical patient and increased susceptibility to infection. Crit Care 2002; 6: 298-305.

[53] Himmelseher S, Durieux ME. Ketamine for perioperative pain management. Anesthesiology 2005; 102: 211-20.

[54] Menigaux C, Guignard B, Fletcher D, Sessler DI, Dupont D, Chauvin $M$. Intraoperative small-dose ketamine enhances analgesia after outpatient knee arthroscopy. Anesth Analg 2001; 93: 606-12.

[55] Kwok RF, Lim J, Chan MT, Gin T, Chiu WK. Preoperative ketamine improves postoperative analgesia after gynecologic laparoscopic surgery. Anesth Analg 2004; 98:1044-9.

[56] De Kock M, Lavand'homme P, Waterloos H. 'Balanced analgesia' in the perioperative period: is there a place for ketamine? Pain 2001; 92: 373-80.

[57] Reutershan J, Chang D, Hayes JK, Ley K. Protective effects of isoflurane pretreatment in endotoxin-induced lung injury. Anesthesiology 2006; 104: 511-7.

[58] Giraud O, Molliex S, Rolland C, et al. Halogenated anesthetics reduce interleukin-1 beta-induced cytokine secretion by rat alveolar type 11 cells in primary culture. Anesthesiology 2003; 98: 74-81.

[59] Kidani Y, Taniguchi T, Kanakura H, Takemoto Y, Tsuda K, Yamamoto K. Sevoflurane pretreatment inhibits endotoxin-induced shock in rats. Anesth Analg 2005; 101: 1152-6.

[60] Takala RS, Soukka H, Salo MS, Kirvela O, Kaapa P, Aantaa R. Gene expression of pulmonary cytokines after sevoflurane or thiopentone anaesthesia in pigs. Acta Anaesthesiol Scand 2006; 50: $163-7$. 